\title{
Peningkatan Hasil Belajar IPA Materi Suhu dan Kalor dengan Media Audio Visual pada Siswa Kelas V SDN 4 Sumberdadi Kecamatan Trenggalek Semester 2 Tahun Pelajaran 2019/2020
}

\author{
Sukriyanto \\ SDN 4 Sumberdadi Kecamatan Trenggalek Kabupaten Trenggalek, Indonesia \\ Email: sukriantos37@gmail.com
}

\begin{abstract}
Abstrak: : Beberapa sekolah di Indonesia belum dapat melaksanakan kurikulum 2013 karena belum tersedia fasilitas sekolah yang memadai. Media audio visual dapat dijadikan sebagai alternative keterbatasan fasilitas yang merupakan alat multimedia yang mampu menyajikan materi dalam bentuk audio, visual, maupun audio visual dalam pembelajaran. Penggunaan media audio visual pada pembelajaran IPA subtema suhu dan kalor terbukti mampu meningkatkan hasil dan ketuntasan belajar pada siswa kelas V SDN 4 Sumberdadi Kecamatan Trenggalek Kabupaten Trenggalek semester 2 tahun pelajaran 20192020. Nilai rata-rata hasil belajar menunjukkan peningkatan yang cukup signifikan yaitu temuan awal $61,05 \%$, siklus I menjadi $64,74 \%$, dan siklus II meningkat menjadi $72,63 \%$.
\end{abstract}

\section{PENDAHULUAN}

Belajar merupakan hasil latihan dan atau pengalaman dari setiap perubahan tingkah laku dan relatif tetap. Hal ini dikuatkan oleh Surtikanti (2008:12), meliputi: (1) belajar merupakan suatu kegiatan berlatih guna memeroleh pengalaman. Berkaitan dengan ini, posisi siswa sebagai pribadi aktif dan dinamis. (2) Posisi guru sebagai dinamisator dan fasilitator untuk siswa saat beraktivitas untuk memeroleh pengalaman belajar. (3) Hasil aktivitas pembelajaran harus nyata, yakni terdapat perubahan tingkah laku secara permanen. Pendidikan di Indonesia perlu menerapkan tiga aspek penting tersebut dalam proses pembelajaran agar terjadi harmonisasi pembelajaran dalam mencapai target-target pembelajaran di sekolah.

Berkaitan dengan pendidikan, program pendidikan di Indonesia telah disusun dengan baik. Namun, sistem pembelajaran tersebut belum terlaksana secara merata. Beberapa sekolah belum dapat mengimplentasikan standar kurikulum yang berlaku karena terkendala oleh ketidaktersediaan fasilitas pembelajaran di sekolah, khususnya faktor pembiayaan dan kesadaran siswa terhadap pentingnya suatu pendidikan untuk masa depan. Hal ini menyadarkan pendidik bahwa pendidikan yang telah dilaksanakan belum sepenuhnya dapat memenuhi kebutuhan ilmu pengetahuan yang bermanfaat bagi kehidupan siswa.

Berdasarkan observasi yang dilakukan di SDN 4 Sumberdadi Kecamatan Trenggalek Kabupaten Trenggalek, fasilitas sekolah yang tersedia belum mampu 
mencukupi kebutuhan belajar siswa pada materi suhu dan kalor. Materi suhu dan kalor termasuk materi yang sulit dipahami oleh siswa. Nilai belajar pada materi ini diperoleh siswa siswa dengan nilai di bawah KKM. Hal ini didukung oleh pernyataan Hamalik (2006:30) bahwa apabila siswa belajar dengan baik, akan terjadi perubahan tingkah laku pada siswa. Begitu pula dengan Syamsudin (2003) yang menyatakan bahwa perubahan tingkah laku tersebut terjadi setelah mengalami proses belajar. Sehingga, prestasi belajar siswa merupakan suatu hasil dari usaha yang maksimal oleh siswa dalam menguasai materi-materi pembelajaran atau aktivitas belajar yang dilakukan.

Hasil belajar merupakan bentuk pencapaian tujuan pembelajaran. Hasil belajar juga sebagai pencerminan penguasaan siswa terhadap materi dan berhasil atau tidaknya guru dalam memfasilitasi suatu pembelajaran. Pembelajaran di SDN 4 Sumberdadi Kecamatan Trenggalek Kabupaten Trenggalek sepenuhnya belum berhasil. Masalah-masalah yang sering muncul dalam pembelajaran suhu dan kalor berupa: (1) Pekerjaan rumah yang diberikan oleh guru tidak dikerjakan, (2) antarsiswa saling mengganggu saat pembelajaran, (3) siswa lambat belajar, khususnya saat mengerjakan soal latihan, dan (4) saat guru menyampaikan materi pembelajaran, antarsiswa terlihat berbicara di luar pembelajaran. masalah-masalah tersebut disebabkan oleh beberapa hal, meliputi: (1) pembelajaran didominasi dengan ceramah oleh guru, (2) belum melibatkan penggunaan media pembelajaran dalam aktivitas belajar, (3) dan pemberian contoh-contoh hanya bersumber dari buku diktat/paket. Muara dari masalah dan penyebab ini adalah siswa kurang minat terhadap pembelajaran tematik.

Pembelajaran berbasis tematikmerupakan suatu program pembelajaran dengan mengelaborasikan satu tema dalam beberapa aspek yang ditinjau dari beragam perspektif mata pelajaran di sekolah (Kardi, 2000:1). Dengan belajar secara tematik, siswa mampu mengonstruksi keterkaitan antarpengalaman, antarpengetahuan, dan antarpengalaman dan pengetahuan untuk menjadi pembelajaran yang menarik (Ibid, 2014:7). Pembelajaran tematik bertujuan untuk: (1) memfokuskan pembelajaran pada satu tema tertentu, (2) mengembangkan beragam kompetensi mata pelajaran yang terdapat pada satu tema, (3) mengaitkan beragam mata pelajaran dengan pengalaman siswa, dan (4)menyajikan pembelajaran secara terpadu.

Dampak masalah dan penyebab pembelajaran IPA di SDN 4 Sumberdadi Kecamatan Trenggalek Kabupaten Trenggalek yaitu tujuan pembelajaran IPA materi suhu dan kalor yang tidak tercapai. Materi suhu dan kalor mencakup tema panas dan perpindahannya pada tema keenam kelas $V$ dengan fokus pembelajaran subtema 3 yaitu pengaruh kalor terhadap kehidupan pada pembelajaran kesatu.

Kalor disebut juga sebagai energi panas. Giancoli (2001:490) dan Sumardi (2007:817) menyatakan panas sebagai energi yang ditransfer datu satu benda ke benda yang lain karena perbedaan temperatur. Panas juga dapat muncul dari bendabenda yang dibakar. Panas dari pembakaran inilah yang dapat membangkitkan gaya untuk melakukan kerja. Adapun Kreith (1991:4) memberikan pemaparan tentang perpindahan panas, yaitu perpindahan energi dari satu tempat ke tempat yang lain sebagai akibat dari beda suhu antara tempat-tempat tersebut. Perpindahan ini dapat terjadi melalui tiga cara, yaitu konduski, konveksi, dan radiasi. Adapun yang dimaksud dengan kalor yaitu banyaknya panas, sedangkan suhu yaitu derajat panas suatu benda. Jika materi ini tidak disampaikan dengan perantara pembelajaran yang tepat, siswa dipastikan akan kesulitan mencapai target pembelajaran.

Media pembelajaran sebagai alternatif pembelajaran yang dapat menunjang tercapainya tujuan pembelajaran materi suhu dan kalor yaitu melalui media audio visual. Asyhar (2011:45) mengartikan media audio visual sebagai ragam media yang dimanfaatkan dalam aktivitas belajar dengan melibatkan fungsi dengar dan lihat dalam proses aktivitas belajar mengajar. Media audio visual memiliki kesan pembelajaran dan mampu menarik perhatian siswa. Fungsi media audio visual sebagai alat multimedia adlah mampu menampilkan bahan pembelajaran dalam bentuk audio, 
visual, dan atau audio visual secara bersamaan. Media ini sebagai media penyampaian suatu informasi yang mempunyai karakteristik audio dan visual. Karena media audio visual telah sering dimanfaatkan dalam pembelajaran, penelitian ini juga memanfaatkan media audio visual dalam pembelajaran IPA materi ajar suhu dan kalor di SDN 4 Sumberdadi Kecamatan Trenggalek Kabupaten Trenggalek karena dapat membantu kegiatan belajar mengajar.

Media audio visual mempunyai peran sebagai media yang dapat mengongkretkan materi pembelajaran. Media ini memberikan pengalaman belajar siswa di SDN 4 Sumberdadi Kecamatan Trenggalek Kabupaten Trenggalek lebih bermakna dan mampu diingat dengan jangka waktu lama. Ha ini dikuatkan oleh Levied an Lents (dalam Arsyad, 2007) bahwa audio visual memiliki manfaat dalam tiga ranah pemikiran yakni meningkatkan rasa ingin tahu (aspek kognitif), membentuk sikap siswa (aspek afektif, dan memberikan berbagai kegiatan berlatih (aspek psikomotor).

Ketiga ranah pemikiran dari manfaat suatu media audio visual tersebut diterapkan dalam pembelajaran IPA agar suasana kelas semakin aktif dan menyenangkan. Sehingga, dengan implementasi media audio visual, hasil belajar IPA materi suhu dan kalor siswa kelas V SDN 4 Sumberdadi Kecamatan Trenggalek Kabupaten Trenggalek semester 2 tahun pelajaran 2019-2020 semakin meningkat.

\section{METODE}

Penelitian ini menggunakan jenis Penelitian Tindakan Kelas (PTK) dengan empat tahap dari Lewis, yaitu perencanaan, tindakan, pengamatan, dan refleksi. Gambar berikut ini merupakan tahapan PTK.

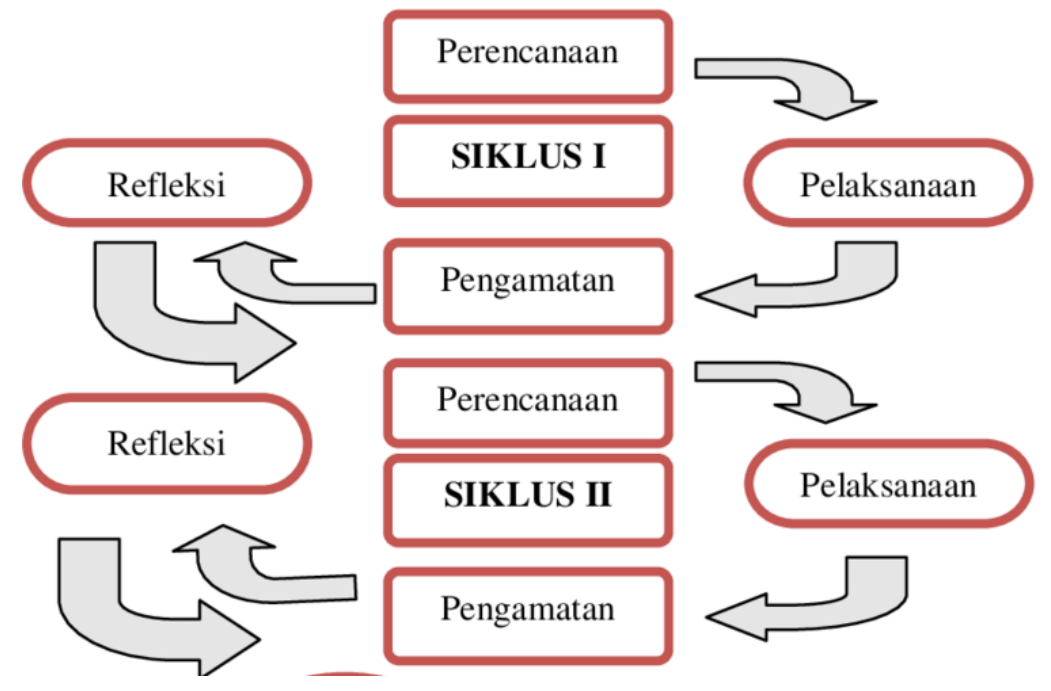

Gambar 1. Tahapan PTK model Lewis

Berdasarkan gambar 1, disajikan tahapan PTK model Lewis mencakup empat tahap. Pertama, rencana (planning) tindakan penelitian ini mencakup seluruh tahapan tindakan meliputi: (1) perencanaan terhadap hal yang diperlukan dalam menentukan solusi atas masalah penelitian yang telah dirumuskan; (2) perencanaan teknik dan alat yang dibutuhkan untuk pengumpulaan data; (3) perencanaan pencatatan data dan pengolahan data; dan (4) perencanaan pelaksanaan tindakan dan evaluasi hasil. Kedua, tindakan (action) penelitian merupakan suatu implementasi dari seluruh planning yang telah disusun. Tindakan ini berkaitan dengan proses atau aktivitas pembelajaran yang sesuai dengan desain pembelajaran untuk mengatasi masalahmasalah pembelajaran. Adapun tindakan PTK ini mencakup dua siklus. Masing-masing siklus terdiri atas dua pertemuan yang berisi pendahuluan, inti, dan akhir. Ketiga, pengamatan (observing) pada penelitian ini ditujukan pada proses tindakan, pengaruh 
tindakan, keadaan dan kendala tindakan, serta persoalan lain yang berkaitan. Kegiatan pengamatan berisi pengumpulan data-data dengan menggunakan instrumen yang valid. Pengamatan ini dapat dilakukan secara kolaboratif dengan guru lain. Keempat, refleksi (reflecting) diisi dengan kegiatan merenungkan kembali tindakan-tindakan yang telah terlaksana (tercatat saat pengamatan). Secara realitas, tahap refleksi mencakup kegiatan menganalisis, menyintesis, menafsirkan (menginterpretasi), menjelaskan, dan mneyimpulkan. Hasil refleksi digunakan sebagai revisi terhadap tahap rencana yang terlaksana dan memperbaiki kinerja guru pada siklus/pertemuan selanjutnya. Refleksi ini juga dilakukan untuk merevisi rencana-rncana yang belum dapat memecahkan masalah pembelajaran.

Siswa kelas V SDN 4 Sumberdadi Kecamatan Trenggalek Kabupaten Trenggalek tahun pelajaran 2019-2020 berjumlah 19 orang siswa digunakan sebagai subjek penelitian. Fokus penelitian ini hanya pada hasil belajar siswa dengan data yang diperlukan berupa hasil tes siswa pada setiap siklus dengan bentuk tes tulis berupa pilihan ganda berjumlah 10 soal.

Data penelitian dianalisis secara kuantitatif dan kualitatif. Data kuantitatif penelitian ini diolah dengan teknik statistik deskripstif, sedangkan data kualitatif diolah melalui paparan naratif. Hasil belajar siswa dihitung dengan rumus: Nilai $=\frac{\text { skor perolehan }}{\text { jumlah skor }} \times 100$

Penghitungan rata-rata menggunakan rumus sebagai berikut. $x=\frac{\sum x}{n}$

Selanjutnya, menentukan ketuntasan belajar secara klasikal dengan persentase, yaitu $\sum$ siswa tuntas belajar

$\sum$ seluruh siswa

\section{HASIL dan PEMBAHASAN}

\section{Deskripsi Kondisi Awal}

Subjek yang diteliti berjumlah 19 orang siswa (11 orang siswa perempuan dan 8 orang siswa laki-laki) pada kelas V di SDN 4 Sumberdadi Kecamatan Trenggalek Kabupaten Trenggalek. Berdasarkan hasil observasi terhadap 19 orang siswa didaptkan permasalahan pembelajaran IImu Pengetahuan Alam. Permasalahan tersebut terinci sebagai berikut. (1) saat proses pembelajaran, siswa cenderung pasif dalam merespon pemberian materi sumber energy panas. Hal ini dipicu oleh kegiatan pembelajaran yang didominasi dengan ceramah oleh guru tanpa menggunakan alat bantu pembelajaran. (2) kejenuhan siswa tampak saat dilakukan tanya-jawab. (3) semangat belajar menurun. (4) guru tidak segera mengatasi kendala belajar siswa di kelas. (5) Guru tidak menggunakan media atau metode pembelajaran. Kelima permasalahan utama tersebut dijadikan sebagai bahan untuk memperbaiki proses pembelajaran IPA melalui Penelitian Tindakan Kelas (PTK).

Pemanfaatan media audio visual telah dikonsultasikan dengan beberapa praktisi pendidikan agar dapat menciptakan kesempatan siswa untuk mengkronstruksi kompetensi yang ada pada diri siswa. Selaras dengan pendapat bahwa Hadi (2008) guru perlu mengetahui sejauh mana perkembangan konstruksi pengetahuan siswa. Konstruksi kompetensi ini dikaitkan dengan kehidupan siswa. Sehingga, siswa mampu menyelesaikan beragam masalah yang dihadapidalam kehidupan siswa. Adapun keadaan awal pembelajaran disajikan melalui tabel berikut. 
Tabel 1

Hasil Tes Kondisi Awal Pembelajaran IPA materi Suhu dan Kalor pada Kondisi Awal materi sumber energi panas

\begin{tabular}{|c|c|c|c|c|c|c|}
\hline No & Skor & Jumlah Siswa & Capaian & Persentase & Kriteria & Ket. \\
\hline 1 & $90-100$ & 0 & 0 & 0,00 & Istimewa & T \\
\hline 2 & $80-89$ & 0 & 0 & 0,00 & Sangat Baik & T \\
\hline 3 & $70-79$ & 6 & 420 & 31,58 & Baik & T \\
\hline 4 & $60-69$ & 9 & 540 & 47,37 & Cukup & BT \\
\hline 5 & $<50$ & 4 & 200 & 21,05 & Kurang & BT \\
\hline Jumlah & 19 & $\mathbf{1 1 6 0}$ & $\mathbf{1 0 0 , 0 0}$ & - & - \\
\hline \% Ketuntasan & \multicolumn{7}{|c|}{$\mathbf{3 1 , 5 8}, \mathbf{0 5}$} \\
\hline \multicolumn{7}{|r|}{ Rata-rata }
\end{tabular}

Tabel 1 menunjukkan kondisi awal bahwa terdapat 6 orang siswa yang tuntas $(31,58 \%)$, sedangkan siswa yang belum tuntas berjumlah 13 orang siswa $(68,42 \%)$ dengan nilai rata-rata 61,05 .

Hasil kondisi awal tersebut memberikan gambaran bahwa siswa sudah terbiasa menyimak penjelasan guru tanpa merespon melalui pertanyaan atau pendapat.

\section{Deskripsi Siklus Pertama}

Pembelajaran siklus I dilaksanakan dua kali pertemuan pada Senin, 20 Januari 2020 dan Selasa, 21 Januari 2020. Tahapan pada siklus I pertemuan kesatu sebagai berikut.

Kesatu, perencanaan. Perencanakan yang dibuat meliputi: (a) menyusun perangkat/rencana pembelajaran yaitu Rencana Pelaksanaan Pembelajaran (RPP) bersama observer dan (b) menyiapkan instrument penilaian berupa tes evaluasi untuk mengetahui informasi penerapan media audio visual dalam pembelajaran.

Kedua, pelaksanaan. Pembelajaran pertemuan kesatu diawali dengan salam, menyiapkan situasi belajar siswa, mengecek kehadiran, doa, penguatan sikap syukur kepada Tuhan Yang Maha Esa, menyanyikan lagu kebangsaan Indonesia raya, dan memastikan kerapian siswa dan kelas bersih. Siswa menyimak penyampaian guru, yaitu tujuan dan manfaat pembelajaran, kegiatan belajar, dan penguatan sikap disiplin. Siswa dan guru berdiskusi terkait perkembangan aktivitas literasi di sekolah. Berikutnya, kegiatan inti sebagai berikut. (1) guru memperkenalkan judul tema "panas dan Perpindahannya" dan subtema "Suhu dan Panas". Kegiatan stimulasi dilakukan guru dengan memberikan pertanyaan kepada siswa agar muncul rasa ingin tahu. (2) Guru menyiapkan media audio visual dengan memutar video melalui layar projektor berjudul "Perpindahan Kalor". (3) Pembentukan kelompok beranggotakan 4-5 orang siswa. (4) Siswa menyimak penyampaian materi melalui media audio visual. (5) Siswa mencatat bagian penting materi dan mengikuti petunjuk-petunjuk yang ditampilkan melalui media. Pada aktivitas ini, guru bertindak sebagai narasumber dan fasilitator. (6) Secara berkelompok, siswa mendiskusikan persoalan yang muncul dalam tampilan video. (7) Siswa dan guru merefleksi kegiatan belajar yang telah berlangsung. Adapun kegiatan akhir pembelajaran, siswa dan guru merumuskan simpulan hasil belajar. Guru juga menyampaikan aktivitas pembelajaran pada pertemuan selanjutnya. Kebersihan kelas dilakukan melalui operasi semut. Doa bersama sebagai penutup pembelajaran pertemuan kesatu. Pembuka pembelajaran pertemuan kedua sama dengan pertemuan kesatu. Namun, terdapat perbedaan pada kegiatan inti. (1) siswa menyampaikan rangkuman materi pembelajaran yang telah dipahami saat menyimak video pembelajaran. (2) Siswa bertanya terhadap sajian video yang tidak dimengerti. (3) Guru memberikan kesempatan kepada siswa lain untuk menjawab atau mendiskusikan pertanyaan. (4) Jika pertanyaan telah terjawab oleh siswa, guru tidak perlu menjawab pertanyaan tersebut. (5) Guru memberikan tes siklus I untuk mengukur ketercapaian 
tujuan pembelajaran melalui media audio visual, (6) refleksi bersama, dan (7) simpulan hasil belajar.

Ketiga, observasi. Kegiatan observasi ini memeroleh hasil berikut. (1) Siswa aktif mengikuti aktivitas belajar dan siswa telah mampu merespon permasalahan yang disampaikan guru. (2) Siswa telah berhasil melakukan diskusi secara berkemlompok. Namun, kegiatan diskusi ini masih tampak sebagian siswa yang tidak serius, diam, dan hanya mendengarkan tanpa merespon. (3) Siswa berani bertanya tentang materi dalam video.

Keempat, refleksi. Tahap ini dilakukan analisis data melalui pedoman observasi, angket, dan hasil tes. Hasil olah data pada tahap ini dijadikan sebagai bahan perbaikan pada siklus berikutnya. Hasil post-test tindakan pembelajaran siklus I disajikan melalui tabel 2.

Tabel 2

Rekapitulasi Nilai Tes Pembelajaran IPA materi Suhu dan Kalor pada Siklus I

\begin{tabular}{|c|c|c|c|c|c|c|}
\hline No & Skor & Jumlah Siswa & Capaian & Persentase & Kriteria & Ket. \\
\hline 1 & $90-100$ & 0 & 0 & 0,00 & Istimewa & $\mathrm{T}$ \\
\hline 2 & $80-89$ & 0 & 0 & 0,00 & Sangat Baik & $\mathrm{T}$ \\
\hline 3 & $70-79$ & 9 & 630 & 47,37 & Baik & $\mathrm{T}$ \\
\hline 4 & $60-69$ & 10 & 600 & 52,63 & Cukup & BT \\
\hline 5 & $<50$ & 0 & 0 & 0,00 & Kurang & BT \\
\hline \multicolumn{2}{|c|}{ Jumlah } & 19 & 1230 & 100,00 & - & - \\
\hline \multicolumn{2}{|c|}{$\%$ Ketuntasan } & \multicolumn{5}{|c|}{47,37} \\
\hline \multicolumn{2}{|c|}{ Rata-rata } & \multicolumn{5}{|c|}{64,74} \\
\hline
\end{tabular}

Tabel 2 merekap nilai tes pembelajaran IPA tema perpindahan suhu dan panas subtema shu dan kalor pada siklus I sebagai berikut. (a) Secara klasikal, nilai rata-rata berjumlah 64,74 ; (b) siswa yang telah tuntas belajar sebanyak 9 orang siswa $(47,37 \%)$; dan (c) siswa yang belum tuntas belajar sebanyak 16 orang siswa $(84,21 \%)$. Data tersebut menunjukkan bahwa perlu dilakukan perbaikan pada siklus II.

\section{Hasil Siklus II}

Aktivitas siklus II dilaksanakan dua kali pertemuan pada Senin, 3 Februari 2020 dan Selasa, 4 Februari 2020. Siklus II dilakukan berdasarkan refleksi pada siklus I dengan perbaikan pembelajaran. Tahapan siklus II mencakup perencanaan desain pembelajaran, pelaksanaan pembelajaran yang terdiri atas dua pertemuan, observasi, dan refleksi.

Siklus II telah memeroleh peningkatan hasil belajar siswa. Adapun hasil tersebut telah terekap pada tabel 3.

Tabel 3

Rekapitulasi Nilai Tes Pembelajaran IPA materi Suhu dan Kalor pada Siklus II

\begin{tabular}{|c|c|c|c|c|c|c|}
\hline No & Skor & Jumlah Siswa & Capaian & Persentase & Kriteria & Ket. \\
\hline 1 & $90-100$ & 1 & 90 & 5,26 & Istimewa & $\mathrm{T}$ \\
\hline 2 & $80-89$ & 6 & 480 & 31,58 & Sangat Baik & $\mathrm{T}$ \\
\hline 3 & $70-79$ & 9 & 630 & 47,37 & Baik & $\mathrm{T}$ \\
\hline 4 & $60-69$ & 3 & 180 & 15,79 & Cukup & BT \\
\hline 5 & $<50$ & 0 & 0 & 0,00 & Kurang & BT \\
\hline \multicolumn{2}{|c|}{ Jumlah } & 19 & 1380 & 100,00 & - & - \\
\hline \multicolumn{2}{|c|}{ \% Ketuntasan } & \multicolumn{5}{|c|}{84,21} \\
\hline \multicolumn{2}{|c|}{ Rata-rata } & \multicolumn{5}{|c|}{72,63} \\
\hline
\end{tabular}

Tabel 3 menunjukkan nilai tes pembelajaran IPA pada subtema Suhu dan Kalor pada siklus II. Berdasarkan tabel 3, dapat diuraikan hal-hal sebagai berikut. (a) Secara 
klasikal, nilai rata-rata nilai hasil belajar siswa yaitu 72,63. (b) Ketuntasan belajar siswa dengan nilai minimal 70 diperoleh 16 orang siswa (84,21\%). (c) Ketidaktuntasan belajar siswa berjumlah 3 orang siswa (15,79\%).

Nilai rata-rata 72,63 telah memenuhi indikator keberhasilan karena di atas KKM sebesar 70 . Siswa tuntas mencapai $84,21 \%$ (16 orang siswa). Dengan demikian, perbaikan pembelajaran IPA telah berhasil dan selesai pada siklus II dengan indikatot keberhasilan $85 \%$.

Refleksi yang diperoleh pada siklus II ini yaitu pemanfaatan media audio visual untuk meningkatkan hasil belajar subtema Suhu dan Kalor telah terlaksana secara optimal. Optimalisasi pembelajaran pada siklus II, mencakup: (1) siswa telah mampu mengomunikasikan pendapat dengan baik. Mengomunikasi pendapa ini didukung oleh pernyataan Utami (2020:98) bahwa interaction means is communication. Komunikasi yang baik akan menumbuhkan suatu interaksi yang baik; (2) pembelajaran telah terlaksana sesuai dengan rencana/desain pembelajaran; (3) media audio visual memberikan kesempatan siswa untuk merespon isi materi suhu dan kalor; (4) media audio visual menunjukkan peningkatan pemahaman siswa; (5) siswa mampu berkonsentrasi dengan baik, baik melalui simakan video materi suhu dan kalor maupun penjelasan guru; dan (6) siswa dapat menikmati aktivitas belajar melalui integrasi media audio visual dan buku tematik yang dimiliki. Hal ini telah dibuktikan juga oleh Lusa (2015) pada penelitiannya bahwa kolaborasi pembelajaran tematik dengan menggunakan model Quantum Teaching dan memanfaatkan media audio dan visual membuat aktivitas belajar lebih baik. Siswa dapat aktif dan terlatih berpikir kreatif dalam kegiatan belajar dan gurupun dapat memaksimalkan proses pembelajaran yang menyenangkan.

\section{Hasil belajar pada Siklus I dan Siklus II}

Pelaksanaan kegiatan perbaikan pembelajaran IPA di kelas $\mathrm{V}$ SDN 4 Sumberdadi dengan menerapkan media audio visual terbukti dapat mendukung kebutuhan belajar siswa pada setiap siklusnya. Berikut ini disajikan rekapitulasi pada temuan awal, siklus I, dan siklus II.

Tabel 4 Hasil Temuan Awal, Siklus I dan Siklus II

\begin{tabular}{|cccccc|} 
Siklus & Nilai Rata-2 & Tuntas & $\%$ & $\begin{array}{c}\text { BIm } \\
\text { Tunta } \\
\text { S }\end{array}$ & $\%$ \\
\hline Awal & 61,05 & 6 & 31,58 & 13 & 68,42 \\
\hline I & 64,74 & 9 & 47,37 & 10 & 52,63 \\
\hline II & 72,63 & 16 & 84,21 & 3 & 15,79 \\
\hline
\end{tabular}

Tabel 4 menunjukkan adanya suatu peningkatan yang signifikan terhadap ketuntasan belajar subtema Suhu dan Kalor pada siklus I dan siklus II. Hal ini juga disajikan melalui gambar 2 berikut ini.

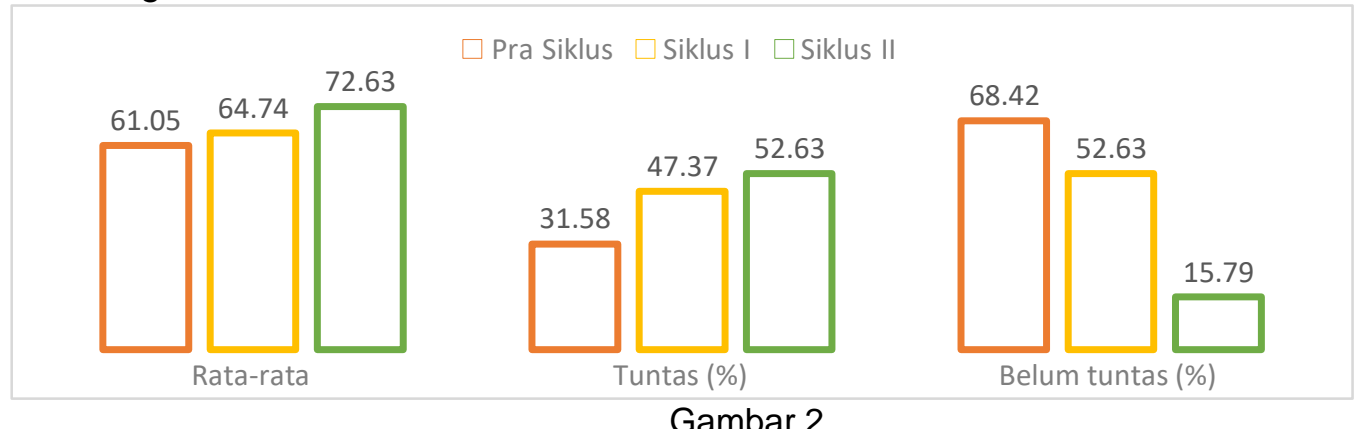

Peningkatan dan Penuruan Ketuntasan Belajar Siswa pada temuan Awal dan Siklus I\&II 
Tabel 4 dan gambar 2 diketahui bahwa kondisi awal pembelajaran sebelum menggunakan media audio visual pada subtema suhu dan kalor menunjukkan hanya 6 dari 19 orang siswa yang tuntas $(31,58 \%)$. Perbaikan desain pembelajaran dilakukan dengan memenafaatkan media audio visual pada pembelajaran IPA subtema suhu dan kalor. Perbaikan pada siklus I meningkat menjadi 9 orang siswa $(47,37 \%)$ dan siklus II meningkat kembali menjadi 16 orang siswa $(84,21 \%$. Hal ini juga dapat ditunjukkan melalui perolehan nilai rata-rata siswa yang terus meningkat, yaitu kondisi awal menunjukkan jumlah rata-rata 61,05 , siklus I meningkat dengan jumlah 64,74 , dan rata-rata siklus II mengalami peningkatan di atas kriteria ketuntasan, yaitu 72,63\%.

Pemanfaatan media audio visual telah mendukung kegiatan belajar IPA dengan memberikan kesempatan siswa untuk berlatih berpikir kritis dan mengonstruksi pengetahuan dan keterampilan siswa melalui stimulus yang diberikan guru. Pemberian pengalam baru dalam bentuk stimulasi dapat meningkatkan kemampuan literasi awal pada subjek (Hapsari, dkk, 2017:178). Stimulus tersebut berupa pertanyaan yang dapat dijawab oleh siswa dengan cermat. Dengan demikian, pada setiap aktivitas belajar, baik siklus I dan II telah diketahui kompetensi siswa dalam menyampaikan pendapat secara spontan. Hal ini karena dikuatkan oleh kompetensi siswa melalui belajar suhu dan kalor dengan memanfaatkan media audio visual. Siswa mampu menyampaikan pendapat dan bertanya merupakan suatu hasil berlatih melalui stimulus media audio visual.

\section{KESIMPULAN}

Berdasarkan analisis data dan temuan penelitian dari dua siklus diperoleh simpulan sebagai berikut. Penerapan media audio visual pada pembelajaran IPA subtema suhu dan kalor telah mampu meningkatkan hasil dan ketuntasan belajar siswa kelas V SD Negeri 4 Sumberdadi Kecamatan Trenggalek Kabupaten Trenggalek semester 2 tahun pelajaran 2019-2020. Jumlah siswa tuntas pada kondisi awal berjumlah 6 orang siswa $(31,58 \%)$. Selanjutnya, dilakukan perbaikan dengan menggunakan media audio visual pada pembelajaran tematik tema perpindahan suu dan panas subtema suhu dan kalor pada siklus I meningkat menjadi 9 orang siswa $(47,37 \%)$ dan siklus II meningkat kembali menjadi 16 orang siswa $(84,21 \%)$. Peningkatan nilai rata-rata ini cukup signifikan, yaitu kondisi awal yaitu 61,05 meningkat pada siklus I yaitu 64,74, dan siklus II meningkat lagi, yaitu sebesar 72,63. Perolehan nilai pada siklus II ini telah menunjukkan kriteria keberhasilan pembelajaran.

\section{DAFTAR RUJUKAN}

Surtikanti. (2008). Strategi Belajar Mengajar. Surakarta: UMS.

Hamalik, Oemar. (2006). Proses Belajar Mengajar. Bandung : Bumi Aksara.

Abin, Syamsuddin Makmun. (2003). Psikologi Pendidikan. Bandung: Rosda Karya Remaja.

Kardi, S. dan Nur, M. (2000). Pengajaran Langsung. Surabaya: University Press.

Ibid. (2014). Prinsip Pokok Pembelajaran Tematik dalam Perspektif Global. Jakarta: Kencana.

Giancoli, Douglas C. (2001). Fisika. Edisi Kelima Jilid 1. Jakarta: Penerbit Erlangga

Sumardi, Yosaphat. et. al. (2007). Konsep Dasar IPA SD. Jakarta: Universitas Terbuka

Kreith, Frank. (1991). Prinsip Prinsip Perpindahan Panas, Edisi ketiga. Erlangga : Jakarta.

Asyhar, Rayanda. (2011). Kreatif Mengembangkan Media Pembelajaran. Jakarta: Gaung Persada (GP) Press.

Arsyad, Azhar. (2007). Media Pembelajaran. Jakarta: PT Raja Grafindo Persada.

Utami, Sri dan Lailiyatus Sa'diyah. (2020). The Development of Negotiation Text Oriented to Higher Order Thinking Skills (HOTS) for Teaching Material with the Context of Life Skills in the Business and Industrial World. Journal Of 
Development Research. 4(2), 97-105. DOI: https://doi.org/10.28926/jdr.v4i2.117.

Hadi, Sofwan. (2008). Proses Konstruksi Pengetahuan Siswa dalam Pembelajaran Perbandingan Trigonometri. Malang: Diploma thesis Universitas Negeri Malang.

Lusa, Herman. (2015). Pembelajaran Tematik melalui Pendekatan Saintifik Berbasis Quantum Teaching Tandur dan Media Audio Visual. Attadib: Journal of Elementary Education. 1(1).

Hapsari, Widyaning, Lisnawati Ruhaena, dan Wiwien Dinar Pratisti. (2017). Peningkatan Kemampuan Literasi Awal Anak Prasekolah melalui Program Stimulasi. Jurnal Psikologi. 44(3), 177-184. 